\title{
Principles of the Development of Transactions Jurisprudence
}

\author{
Mohammad Sadegh Elmi Sola ${ }^{1}$, Mohammad Taghi Fakhlaei ${ }^{1} \&$ Mehdi Moradi $^{1}$ \\ ${ }^{1}$ Department of Jurisprudence and Principles of Islamic Law, Ferdowsi University of Mashhad, Iran \\ Correspondence: Mohammad Sadegh Elmi Sola, Department of Jurisprudence and Principles of Islamic Law, \\ Ferdowsi University of Mashhad, Iran. E-mail: sadegh.elmi37@gmail.com
}

Received: September 4, $2016 \quad$ Accepted: October 2, $2016 \quad$ Online Published: December 29, 2016
$\begin{aligned} & \text { doi:10.5539/jpl.v10n1p252 } \\ & \text { URL: http://dx.doi.org/10.5539/jpl.v10n1p252 }\end{aligned}$

\begin{abstract}
When considering the jurisprudence despite the apparent integrity in the whole structure and nature, from the perspective of subject-internal divisions, differences can be seen that cannot be denied. Classification of different sectors of jurisprudence on issues involving, apart from a facility that creates for the visit and study is the evidence for the existence of differences in the divider. Attention to these differences is underlying of some today's theories. For example, facing with increasing developments of social phenomena and the need for flexibility and dynamic of jurisprudence, a theory is partly accepted that refers to the existence and attention to constant and variable domains in the jurisprudence provisions. The result of this approach generally introduces the domain of changes as transactions jurisprudence that when necessary has the ability to change, while constants are worshiping jurisprudence that stability is considered a fundamental pillar of their validity. That jurisprudence in the area of variable transactions can be seen transform and synchronize with changes is originating from nature that is the distinction of this part from other areas of juridical. In other words, the other property of transactions jurisprudence that originates from features such as the guidance of the commandments in this passage, arguing the provisions for the detention of worship section, religious orders and, ultimately, the possibility of understanding Sari materials for concealment of worship materials on human intellects causes that jurisprudent not considered its structure far from the availability of human reason and by understanding its materials provides the extended field and at the time of considered non-interest permit to change easily. This article briefly from these special privileges of transactions jurisprudence as the principles of development provides an analytical report.
\end{abstract}

\section{Introduction and Statement of Problem}

The teachings of Islam, including jurisprudence from the beginning have been introduced ${ }^{1}$ (Holy Quran) with the claim that are Mana, eternal and pervasive teachings and basically are the requirement of the last divine message that has a systematic program, coincide with the end message of revelation and prophecy ${ }^{2}$ (Mázandaránı), so it is said: "Islam is a religion that consider all aspects of life and has nothing to negligent. Easy and difficult, and small and large..." (Tabatabaei, 1984) and it is clear that jurisprudence in the various aspects of human life from such finality and completeness is evaluated.

One side of the extent of the products offered is affected by the importance of the issues that jurisprudence considers it responsible for stating a pious way and behavior because human life -by the legal interpretation "required action" - covers several areas, sometimes associated with individual life and sometimes is related to social interactions with fellow and yet related to the manner of his conduct with nature and, most importantly, the relationship with the creator and the source of universe. A program that claims universality consequently for each of these areas should provide specific teachings. In fact, depending on the difference of issues, we are seeing a targeted separation that has been conducted differently.

The distinction of each of the chapters and parts is matter, purpose and scope of the issues that should be stated

\footnotetext{
${ }^{1}$ In many verses of the Quran is referred to this meaning, for example, see: Sura Anaam, verse 38, Surah Naml, verse 89, Surah Anaam, verse 59, Surah Al-Maede, verse 3, Surah Shura ', verse 13, Surah Naml, verse 75, Surah Saba, verse 3.

${ }^{2}$ The claim of comprehensiveness of Islamic teachings in addition to the verses in the words of the Prophet (pbuh) has had several aspects, for example, see: Kelini, Mohammad Ibn Ya'qub, al-Kafi, vol. 3, p. 118, Dar Al-Kotob Islamiyah, Tehran, fourth edition, 1407. In the description of this hadith says: "the meaning of the hadith, what you need is in the Qur'an that what need from religious issues and provisions and these traditions not consider ontological sciences." Mázandaránı, Malasaleh, describing the Kafi principles, vol. 2, p. 335 and p. 361 and 366.
} 
and is placed the source and criterion of division.

The owners of science of those religious teachings that are associated with worldly affairs (Amoli, 2000) and have a common comorbidity (Barraj, 1984) and must have the intention of obedience and closeness (Shahid Aval, 1997) and this is why they have inherent utility (Kashef Al-ghata, 2000) and in the way of human evolution have recent effects and related to future (Shahid Aval, 1974) as the worship and those who lack these characteristics are inserted in other chapters.

According to the same attention and respect to the subject, a part which was related to set temporal relations and the protection of human survival depends on them have divided into chapters such as transactions, trials and criminal sentences ${ }^{3}$ (Ghazali, 2000) (Although in the title of the chapters mentioned some differences can also be seen, but the nature of the subject is unaffected).

Fundamental distinction of jurisprudential discourses is not limited in these cases and can also add other items such as against the total worship, almost fulfill other areas is not subject to the intention and the individual authority is involved that is covered by some of them (Ibn Albaraj, 1973; Shaykh Tusi, 1996).

Scholars refer to this breadth of subjects as an unreasonable point for Islamic jurisprudence, but with this point that is referred to integrity, it should be also spoken of the finality of jurisprudence, explaining that jurisprudence raises itself the last godly life program and yet eternal life ${ }^{4}$.

A problem is for the claim that somehow its basis is challenging: Increasingly, we are seeing developments and changes in human life and are not covered adapting to changes over time, jurisprudence should also provide program and a method befitting situation. Although the development doesn't cover all spheres of life and human life and various human dignity of all not accept it uniformly, and also this is due to the lack of attribution and citation of evolution and development to the external facts because they place within their existence and excellence and growth considers characteristic of culture and human communication that will be changed with shift approach and discover the facts of the universe and recruit new tools. However, it is necessary on this unstable part, jurisprudence has the necessary dynamism and flexibility to not remain serious negation on finality and causal claims on inefficiency ${ }^{5}$ (Motahhari, 1975).

Long ago the Sharia compliance issue has become jurisprudence obsession with the changing world and in order to solve this problem, researches have been done. One of the earliest views on the issue is to pay attention to the constant and variable domains in jurisprudence ${ }^{6}$ (Ibn Ghayem, 1987). The main foundation of this view is based on the acceptance of separation between that part of the teaching related to unprecedented phenomena, scientific and technical arrangements with those that are always stable and durable ${ }^{7}$ (Tabatabai, Excerpts of Islam). Regardless of the critics and challengers and regardless of the views that their base is based on the theory, the speech is undeniable in it, but it is necessary to clearly identify the scope of each of the areas.

Variables $^{8}$ (Ibn Ghayem, 1973) in contrast with constants are those regulations that are related to time and

\footnotetext{
${ }^{3}$ One of the oldest divisions of jurisprudential discourses is as follows that is done by Ghazali the thinker of Shafie and is exploited by scholars after him. Ghazali, Abu Hamed, Rehabilitation of Sciences of religion, vol. 1, p. 3, Dar Ibn Hazm, Beirut, 2000. In Shie jurisprudence, the oldest project is seen at a ceremony of Sallar bin Abdul Aziz Deilami (AD 448), Mohazab Qazi Abdul Aziz bin Barraj (481 AD) and Kafi Abu Alslah Halabi (from the middle of the fifth century). Abu Alssalah Halabi considers religious duty on three types as follows: worship, prohibitions and commandments, see: Halabi, Abu Salah, al-Kafi Fi al-Feqh, Maktabeh Amir Al-Momenin, Isfahan.

${ }^{4}$ For example, traditions that explicitly implies this sense, see: Kelini, Mohammad ibn Ya'qub, Al Kafi, J1, p. 58 and Nahj al-Balagha, sermon $189,12$.

5 "Of course, an eternal law if it wants to surround all variable forms of life and offer solutions to all problems and solve every problem for certain, it should have a kind of dynamism and mobility and flexibility, not be solid and inflexible, then we must know how Islam shows different solutions in different forms of life. Certainly mystical secrets should be hidden in the system of Islamic Law to be able to overcome this enormous problem. Mother and source of all secrets and mysteries is the spirit of Islam and its total dependence on human nature and society and the world. "Motahhari, Mortaza, the finality of prophethood, pp. 71-72, Sadra, Qom, 1975.

${ }^{6}$ The most lasting interpret in this context is in the words of Ibn Ghayem (691-751 BC) in the book of "Aghaseh Al-lahfan" vol. 1, pp. 349-369 Maktabeh Wahbe, Cairo, Fourth Edition, 1987.

${ }^{7}$ Tabatabai says: "Islam distinct its regulations in two types of distinct and separate: fixed regulations and variable regulations. (Excerpts of Islam, p. 73, published by Jahan Ara) fixed rules: rules and laws that are established due to the requirements of fixed and uniform nature of human (The same, p. 76). Islam called this section of the provisions as religion and law that is based on the creation of man and his special specifications. Variable regulations: rules and regulations that are temporary and local (or any other specific aspect) and different with the way of life. This part can be changed by the gradual progress of civilization and change and creation and remove new and old methods" (The same, p. 68).

8 "Variables are the provisions that may be changed as a result of various factors and conditions. These factors can be divided into 5 main groups: 1. Time 2. Location 3. State 4. Purpose 5. Target".
} 
spatial certain conditions and are different in different societies ${ }^{9}$ (Ibn Abedin. 1973). This statement in fact refers to this entry that the God to those provisions despite constant rules and general principles, not imposed specific details and final sentences, but always a subject to the conditions around them, and yet, as it is clear from fixed meaning, a set is found that at any time and spatial condition cannot accept the possibility of change ${ }^{10}$ (Ibn Ghayem, 1973) and stability, and durability are an integral part of it (Sadr, 1987), in other words "any cancellation, allocation, change and copies in the fundamental principles of religion don't take place according to religiously accountable and time and spatial circumstances, and whatever be established cause, condition, necessary, will be the same (Shateby, 1997). The cause of this issue is stated legislation compliance with development the nature of the provisions.

Theorists ${ }^{11}$ (Enayat, 1991) due to the nature of the jurisprudential teachings have noted a fact that development and change are related to transactions jurisprudence and stability and durability of worship characteristics ${ }^{12}$ (Holy Quran). Some innovators so far as and believe that basically the jurisprudential teachings in related fields of social life follow to institutionalize the core values and hence somehow have denied the existence of entry into force jurisprudence in the field ${ }^{13}$ (Mojtahed shabestari, 1996). However, the logical consequence of the issue of accepting stability and change in provisions will be attentive and involvement to time and place elements in ijtihad ${ }^{14}$.

The summary of this theory and common views up and along with it should be considered in assigning flexibility and coordination with social developments to transactions jurisprudence ${ }^{15}$ (Moghniye, 1989), of course, it should not be interpreted that the judgment of God itself will change, but change occurs in different vehicles ${ }^{16}$ (Ansari, 1993) including changes in issue ${ }^{17}$ (Amadi, 1986) that as a result of God's judgment on the new container with different shape and appearance is provided (Zarqa, 1952).

Allocating development to transactions jurisprudence is originated of its nature because jurisprudence in the fields is based features that cause to accept the development and on the other hand, not be compatible with stationary under any circumstances. It can be noted to the funds in this area that suggests a fundamental distinction with other parts of the jurisprudence. Even though the relationship in the following terms can be seen that through which can validate return of some to a unifying issue, but as it is clear wording and the expressions used in each is becoming the cause of a special title.

What is referred should be considered an incomplete inductive in the principles of development or more accurately the principles of acceptance of development in transactions jurisprudence. The principles refer to a distinctive and privileged nature of jurisprudence in this area and put an image near the juris consult to allow more evolve and change with more flexible by help of it. These features will be briefly considered in the

\footnotetext{
9 "Many of the provisions with the time difference will be different, to change its common law or because of the occurrence of necessity or corruption of time, in a way that if the first sentence remains, it causes to harm people and with the rules of law which is based on discounted and easily and losses and corruption for the survival of their world."

10 "Fixed principles, not only cannot be changed in terms of Islam, but at all times should be the principles of human life and it is inherent and if the nature is stable under any circumstances, no change occurs in it."

${ }^{11}$ Mohammad Abdeh, distinguished between the provisions of worship and transactions and said the Quran and Hadith have established detailed rules about worship, but on transactions of some relationships between people only convinced on expressing general principles and adapting them on the particular circumstances of life of each period is in responsibility of people of that era.

12 An example of the verses that indicates the lack of variability of law in worships, See Surah Nisa, Verse 103 of Surah Baqarah, verse 183.

13 "What causes family relations, social relations, government, judgment, punishment and like these exist in book and tradition as signatures or signatures with the adjustment, innovation of book and tradition is not to determine the eternal laws for family legal relations or legal relations of society or the problem of government and like it. In these signatures what is immortal, is "the principles of values" that is the aims of reform and modifications of the Book and tradition and intervention is inspired of it.

14 "Time and space are two crucial elements in Ijtihad. Something that in the past has a sentence, apparently the same issue in the political, social and economic relations of a system, it is possible to find a new sentence. This means that detailed knowledge of the economic, social and political relations, the first issue that apparently is not different with the old one, really become a new issue that inevitably will require a new sentence. The priest must surround the issues of his time.

${ }^{15}$ Mohammad Jawad Moghniye considers constants as beliefs, worship and issues of inheritance, marriage and divorce and introduces transactions the variable domain.

${ }^{16}$ For an example, the issue that by necessity of need, its sentence is changed, consider: the jurists have said: Making and carving statue of the organism, according to the Imam (AS) is forbidden. Sheikh Ansari writes: If it is needed and wished to build objects that are similar to God's people, it does not seem to be anything wrong in making it.

${ }^{17}$ For example, changing the subject and consequently sentence can be noted the issue of sale blood as follows: what has changed today is the quality of issue, a sentence that was said previously about the sale of blood: Whatever there is no benefit in it (lawful benefit and rational intention) it is not permissible its purchase and sale and now the Sale of blood is under this title: what has the benefit and rational intention, its transaction is permitted (same) and this is the cause of changing the sentence.
} 
following:

\section{The Ability to Understand the Materials of Provisions on Transactions}

Basing provisions on materials and corruption is considered the purpose of jurisprudence so that it was said, "the purpose is the canonization of sentence or benefit or disposal of loss or a set of both to the Lord save the people from harm and reaches to benefit" (Horr Ameli, 1987).

This irrefutable principle, regardless of commandments and prohibitions of the legislator is the result of interests and corruption that lies in the nature of actions and objects and is the reason of forging provisions (Khoi, 1990). Among principled scholars, founding provisions on materials and corruption is a granted and undeniable matter (Saberi, 2006) because some have considered the issue of adherence to the commandments and prohibitions of interests and corruption as the part of the necessities (Buty, 1984). Despite overcoming Ash'ari thinking among many Sunni theologians that nor consider God's commandments as reason, some Sunni scholars have not been denied provisions on the materials of people and the true evolve. Even existing opposition that is attributable to (Ghazali, 1997) Zaheriye can be justified that the inability of priest in compliance with the provisions is in accordance with interests and also due to his inability to understand the facts as sentence (Shateby, 1997).

The main subject is that rights and duties are to observe interests and disposal of corruption that ensure the responsible interests and society around him. In fact, "the law seeks to protect 5 things and that is to keep the faith, soul, mind, generation and wealth and what caused the survival of these five cases is benefit and what caused its decline is evil and its disposal is benefit" (Naeini, 1989) "So religious duties is to maintain its purposes among the people..." (Motahari, 1955).

Derived from the word and the subsequent complex topics is raised and is considered. For example, although the issue to prove religious purposes is a dispute, but a step before it should be noted that the principle of possibility of surrounding intellects on understanding interests have not been widely accepted (Khomeini, 1999).

Some thinkers by denying mysterious and strictly secret aspects for the provisions have considered basing the provisions on criteria and cover interests contrary to rationality of religion. In contrast, a group of Sunnis generally introduces pure intellect and independent of the provisions incapable of understanding the principles of provisions, and consider the only rely on the provisions the way to achieve provisions. A group has considered achieving to criteria probable and not considered this issue in all the jurisprudential discourses as the same and by the separation of worship from other areas to the most complicated subjects in terms of structure, the various aspects of the human soul and elegance that face comment on this issue with numerous reflections, access wisdom and understanding of criteria is denied in it and refers to dependence of intellect in worship provisions and considered the increase of inability to understand in the worships from the causes of grace on other orders (Shateby, 1997). At the same time, a close acceptance for public among both Shia and Sunni in non-worship refers to the possibility of understanding and getting criteria (Shahid Aval, 1974). In other words, to the extent that worship cannot be considered with intellect only and obtaining criterion and to the extent, intellection in transactions is not faced with much more difficulties and can find understandable criteria and development, although without the help of quotes and texts ${ }^{18}$ (Makarem Shirazi, 1995).

\section{Arguing ${ }^{19}$ Transactions Jurisprudence}

Religion is always associated with the worship and the main demand of any religion of its followers is unquestioning obedience to its orders. Mentioned earlier that undeniable principle implies that provisions comply with the interests and corruption and interests and corruption in the transactions jurisprudence is understandable for intellect. In this paper, we'll investigate the other side of this principle. Here we talk about the fact that where and to what extent the cause and meaning of the state of provisions and regulations is clear and available and has the functionality to be extended and the principle in legal different fields is arguing or worship? Nevertheless, as proof all provisions are defective and based on wisdom are established and the purpose of the discussion relates to the proof.

From the research of religious leaders obtained that believe to worship is some extent which may be considered the consensus of judgment to this principle in this regard. Stipulations of Shiite scholars in different fields of

\footnotetext{
${ }^{18}$ There are moderate views in Shiite thinking that somehow have accepted the understanding of the criteria in all fields, for example: "our though is more for criteria in transactions, because the matters are common law and legislator signs, but less in worship. But this does not mean that in worship, we can never find criteria. In many forms of worship may be criteria to be found"

${ }^{19}$ In the principled so-called of Sunni, the term "Maghul Al-Mani" has been used against worship: "What God has legislated if its sentence is revealed to us, we call it reasonable otherwise we call it worship." Ibn Abedin, Mohammad Amin bin Omar, The margin of Rad al-Mokhtar Ali Al-dar Al-Mokhtar, vol. 1, p. 483.
} 
worship suggest this public acceptance (Bohrani, 1983). Its philosophy is reported to the subjection interest and obedience and test of people to the commandments of the God. In contract, the allocation of detention on worship, a group of owners of Sunni rejected this and in all religious orders have established the principle of rationality and have gone to the point that accepted comparability of all provisions to when there is an included sense in them and believe that principle is arguing in all texts (Hassani, 1995).

In any case, the prevailing view considers "the provisions of worship with the secrets that there is no way for intellect to their perceptions with details although understand their existence in whole and principally" (Ibn Ghayem, 1973).

The situation is changed in the transactions jurisprudence and considers this field as the area of causal and reasoning. Although in some cases, there is authoritative things that way on gratuity to the meanings and causes is blocked and no way but stagnation of cause and resorting to narration in them ${ }^{20}$ (Shateby, 1997) but the dominant reputation in this section except in exceptional cases is the originality of cause and permit the development in the texts.

In addition to reasons that some have stated for proving the principle of arguing ${ }^{21}$ (Shateby, 1997) it should be noted the rationality of Islamic teachings. Since tangible social affairs are closely related to human life, whatever the field of rules is argued is more accepted and helpful. In general, "people are more willing to accept the reasonable provisions, according to the interests to accede to dominate and overcome anger and bitterness" (Ghazali, 1997).

\section{Classification of Provisions of the Transactions}

In many verses of the Holy Quran is warned that some decrees and orders of the former are common on its descent and has been signed by the Quran ${ }^{22}$. Some traditions according to a group indicate the meaning. Historians have noted of a set of traditions and rituals of Arab that have been signed and endorsed by Islam. Moreover, in some cases, rejection or modification is observed (Al-Baghdadi, 1981).

Increase issues facing scholars that originated from several factors led to a group in some issues that refers to "Sharia recess" face to the validity of pre-Islamic rituals and laws what is popular in Shi'i jurisprudence as "Istishab precedent laws" in validating the non-obsolete parts of the pre-Islamic laws (Tabatabai, 1952), and in fact, the concept has been considered of accepting signatures in precedent provisions.

In one sense, God's decrees and provisions can be divided into two parts:

\footnotetext{
20 "When it became clear that in the habits what predominate is meanings and causes if in this field, a case of worship was found inevitably forced to submit to it and stopped at the border. Such as this the request of dowry in marriage, the need for slaughter in a specific member from animal, assumptions set out in inheritance, the number of Iddah months in divorce Iddah and death and matters as these that intellect not understand their detailed interests to be compared to other things, however, we know that the valid conditions in marriage such as permission of parents, or dowry and like it to recognize marriage is depravity, or we know that the assumptions of inheriting in terms of the relationship with the dead have been identified or is the purpose of Iddah and ensure not having a child of a woman and stay safe from mixing hydrology, but these are general things, like that in the field of worship, humbleness and worship to God is the cause of canonization of worship, but this value (awareness to criteria and interest) doesn't require analogy on principle to be said therefore: If, for example, on the marriage, illicit marriage with other signs are recognized not need to conditions in law or if on Iddah ensure to not having a child of a woman, don't need to legislate of Iddah"

${ }^{21}$ Shateby efforts to prove his claim in accepting arguing principle and gratuity to meaning and causes in fields of transactions with the help of contextual reasons. The whole of his reasoning is as follows:

1) Induction of the legislator provisions indicates the truth and legislator in this area follows to realize the interest of people and his provisions is based on these interests. Thus, it is seen that a single object in the mode or form that interest is in it considered allowed and in the other assumption that an interest is not in it or a prosecutor was involved is forbidden. For example, swap money with money in the form of sale is not correct, because it is not advisable. But in the form of debt is correct because it realizes interest.

2) The legislator numerously has expressed reasons and wisdom in the provisions of habits and in most cases agued "appropriate" that if offered on human reason, accepts it. We understand that the intention of the legislator in this field is to follow the meanings and causes, not stop at the border of texts. In other words, the legislator has stipulated in the provisions of transactions that at the time of common law, people considered it as a remedy for pain and well understood of this truth, not that like some contemporary legal approaches that not only be a remedy for pain, that also increases the pain. This is what some legal theorists have spoken of it in the form of a rule and that in legal possession, the principle is to discount them based on the amount of possessions and customary practices, this means that the legislator follows the the same path that human reason itself follows it or at least accepts it.

3) In periods of recess of the apostles, trust to causes and meanings and interests of the people is not covered and they rely on this principle in organizing work with people, and the law has come to add the details. In other words, at this point what the law stipulates is complementation on the way in which people have in the transactions.

${ }^{22}$ In some verses, some common jurisprudence provisions have been reported among the religions of Ebrahimi. See Surah Baqare, verse 182. See also in this regard: Surah Maryam, verse 31 of Sura Anaam, verse 72 of Surah Al-Ma'idah, Verse 48.
} 
Established provisions ${ }^{23}$ (Ibn Manzur, 1983), or provisions that have been issued by the legislator and not had a background in common law and among intellectuals, and the executive provisions (Ibid), or credit matters that common law and intellectuals have credited them, ... as inheritance and marriage and... (Mohaghegh Damad Yazdi, 1984; Valaiy, 2011) academically when new content is considered by the legislator, it is mentioned as an establishment in contrast, if the purpose of emphasizing is used in the meaning of the former theme, re-called signature is used (Jarjani, 1884).

The existence of establishments and signatures of the legislator is not denied ${ }^{24}$ that in which sections "more" signatures can be seen. Shateby as a character in the purposeful perspective by separating normality from worship for the law in this respect is considered the complementary role and refers to the signing of provisions and positive traditions before Islam (Shateby, 1997). Ghazali has also mentioned the secular nature of the jurisprudence in transactions (Ghazali, 1991). There are perspectives among Shia scholars that have considered legal statements in this area as intellectual and emphasis properties (Mohaghegh Heli, 1985).

The absence of specific arguments in the fields of transactions caused to be increased the tendency to execute all or most of the provisions of transactions ${ }^{25}$. Over time, the verses such as "transaction on your compromise" ${ }^{26}$, "Allah has permitted sale"27, "fulfill"28 has attracted the attention of Shi'ite and Sunni scholars to the common law of provisions of transactions (Mohaghegh Qomi, 1991).

In short, the religion dealing with everyday life and common practices in humans, not dealt with the position of denial and sometimes has accepted and emphasized it completely. It is clear that prove and accept is in the place that the existence of conducts are not incompatible with maintaining social order and facilitate people's livelihood, such as most of the rules and regulations concerning contracts of course sometimes these useful procedures are accepted by adding some qualifications and conditions. The phenomenon of execution is referred to interest in the plane. The origin of rule of plan before verifying the legislator is controversial; however, the collective wisdom in its creating cannot be rejected. The result of this speech acknowledges the origins of humanity in most fields of transactions jurisprudence with the confirmations and modifications of the legislator. The result of distinguishing established provision from executive provision is that in established provision, conditions, the scope of the judgment is derived from the legal evidence; While in executive sentence with respect to the common law and the attitude of the intellectuals and the execution by them at the time of its signing can be achieved to the terms and conditions of the sentence. Execution in fact referred to the common law and by the investigation exclusively in the specific time tradition has not been specified explicitly in the texts. So extend the matter and involving common law of other times in the regulation of social and economic relations should be recognized (Parsley Langroodi, 2001).

\section{Guidance of the Commandments of Transactions}

In principled literature of Shi'ite particularly recent years, Movlavi and Ershadi provisions are taken into consideration. "The matter is divided into divisions, including Movlavi and Ershadi, Movlavi matter is a matter that agent to independently is considered and to carry out or leaving it independently good and evil actions is associated, most of the orders that are in the book and tradition are from these orders as prayer, fasting, Zakat. Ershadi matter is a matter that agent to independently is not considered in fact, Ershadi orders is guidance and notes to main commands and tasks and Movlavi are not the purpose of legislator without them and will not be legislation, and, inevitably not have independent rewards and punishments, and obligation and obedience. Many of the orders issued by God Almighty in the Holy Quran and orders and decrees of government issued by the Prophet (PBUH) and the infallible Imams (AS) are Ershadi orders" (Meshkini, 1969; Montazeri, 1987).

From the definitions can clearly understand in Ershadi matter except the receipt of interest not followed any purpose and basically refers to sin oppose to it is negligence. The formal sense of demand in Ershadi matter is that except the interest that guide it in terms of common law and intellect on obedience and disobedience will not be associated reward and punishment. Instructions to patients on medicines use is an excellent example of the use of Ershadi orders by stating that failure to follow doctor's orders not improve patient and is not an associated

\footnotetext{
${ }^{23}$ The word establishment means to begin and establishment.

${ }^{24}$ Some have argued of the executive provisions in Islam for acceptance of the common law near legislator (Ziaee Bigdeli, 1987). In contrast, a group has argued against this notion (Mohammadi, 2004).

${ }^{25}$ In this regard, see: (Makarem Shirazi, 1989; Naeini, 1991; Bojnoordi, 1997).

${ }^{26}$ Surah Nesa, verse 29.

27 Surah Al-Baqare, verse 257.

${ }^{28}$ Surah Maeidah, verse 5 .
} 
effect. Overall Ershadi orders against Mavlavi guide us on what itself is reason without the rule of law in this regard establish or enact new rule. By mentioning this introduction, it should be said "on transactions, there are no religious orders and prohibitions that task provisions are Movlavi and are only Ershadi" (Hosseini Rouhani, 1998). In different fields of jurisprudential issues, guidance of orders in transactions is stated ${ }^{29}$ (Ibid). Assign Ershadi orders to the fields of transactions indicates another fundamental distinction of this part of the law (Montazeri, 1992).

Accepting the existence of the Ershadi matter in the transactions jurisprudence ${ }^{30}$ (Tabatabaei Yazdi, 1999), according to what passed in the introduction of this section implicitly acknowledged the wisdom capabilities in this area and it is clear to researchers that the involvement of the reason has outstanding effects including when the reason changes the criteria in the former inevitably reconsider its sentence, and consequently, Ershadi matter that is in the issue will not remain in its force and is not binding and must be followed worthy replacement, while the situation in Movlavi orders is not as this and intellect, not has a way to criteria to If authentication issued other sentence and, of course, follow a result but stability in Movlavi orders.

\section{Analysis and Conclusions}

Perhaps there cannot be provided an appropriate justification for non-interference of some titles that as a feature was mentioned and found a closeness in the meaning of the concepts, but as it was stated brevity, the purpose was to state independence characteristics in the field of transactions jurisprudence in a broad sense that depicts a distinctive nature in front of the jurisprudence of worship. Although both fields belong to an intellectual and ideological system but each of them contain and follow tools, equipment and the different purposes.

Two basic truth becomes clear from examining the divine law, first jurisprudence in transactions involving the rules, general and basic provisions as well as examples of adapting rules and general provisions on minor events and the other, the silence of legislator from the expression and legislation of many provisions in this section is meaningful and is to maintain compatibility between the man and the circumstances of time and place.

Because interests based on the difference of time and place and conditions of people are different it will be clear that the provisions of interests are also variable (Ibn Ghayem, 1973). Thus, despite the affirmation of the principle of religious purposes, the only provisions of those purposes in accordance with the provisions and circumstances change and this is considered a positive point to this intellectual and ideological system and it is clear when a sentence would be changed depending on the needs it will be more successful and efficient (Sobhi, 1982).

From what was said understood that in the fields of transactions is not such this that legislator of religious truth as seen in worship is adopted and contrary to the fields of beliefs, provisions of the transactions are not constant and firm truth, but are the result of habits and common law and natures that have been agreed upon. Seeing that they have existed before the law and the law, not involved in creating them and are not the result of his fraud and condition. The jurists also have confidence in common law and to prove many of the rights have been clincher to it as far as explicitly or implicitly, there is no prohibition of the legislator, transactions between individuals are allowed to take effect and more importantly, most of the provisions achieve the fields of transactions from the general principles and general rules contrary to what is implied in spiritual issues can be seen that the text of pretext is deduction and finally, the consensus is the basis of the ruling. "legislator in legislation of the provisions on transactions is arguing in most of cases since the judgment presented on human reason accept it and this is the proof that legislator has intended following the meanings and causes not stop at the border of the provisions and we explained that in transactions jurisprudence, what legislator has referred are guidance mainly and guide us to reason sentence.

Attention to the developments in transactions jurisprudence that is as a result of its executive and common law structure clearly indicates the transformation of this area. For example, the issue of validity and binding transactions is a subject that long faced with resistance of jurists (Shahid Sani, 1991; Bohrani, 1983) and until recent scholars (no means common in the classification of jurists) from the Shafi'i (Ibn Qudama) and all Shia scholars (Allameh Helli, 1992) were not considered until over time, influenced by the common law and attention to the nature of the fields of transactions considered contracts as customary forms and tend to executive all or most provisions of the fields of transitions was increased.

In Sunni jurisprudence, the issue should be considered with a fundamental difference. Some Sunni views before

\footnotetext{
29 "Permissibility in transactions is guidance," (Hosseini Rouhani, 1998), elsewhere: "The arguments for the necessity of troth to contract is guidance" (Khomeini, 1996).

30 "In all fields of transactions except rare cases, it is common that religious commandments can be transferred on guidance."
} 
separated from the spheres of life of the Prophet (PBUH) and inspired by their accepted traditions ${ }^{31}$ (Moslem Ibn Al-hajaj, 1985) evaluated the world governance to the people entrusted while Shiite thoughts until recently even compared to change contracts as passed showed resistance and it was considered in religious forms and not customary. The difference in the attitudes reveals itself distinctly.

In total, the result of accepting executing is the guidance of commands and the ability to understand the criterion in a sentence and originality of arguing conceptions with a validity of involving intellect on the one hand and the inclusion of common sense on the other hand as the origins of jurisprudence in the transactions. When we accepted common law in the sentence therefore with its change considered the way to change it, otherwise, except the rigidity and inflexibility will not have any result and also sooner or later pushed jurisprudence into a corner and give to the other competitors the space of power and extension. Accepting flexibility means while considering sentence as legality at the same time not alienating the modern context and has taken a modern form $^{32}$. Development in transactions jurisprudence will follow good results that cannot mention it here, perhaps it can be relied on the point that through the accepting flexibility of transactions jurisprudence, a response against internal and external attacks on the body of jurisprudence is presented.

\section{References}

Al-Baghdadi, M. H. (1981). the book of Al-Mahbar, Matbae Al-daere.

Allameh Helli, H. Y. (1985). Kashf Al-Morad Fi Sharh Tajrid Al-Eteghad, Institute of Al-Nashr Al-Eslami.

Allameh Helli, H. Y. (1992). Tazkera Alfeqha' (Vol. 10). institute of Al al-Bayt peace be upon them, Qom.

Amadi, Seif al-Din. (1986). principles of provisions (Vol. 3, 2nd ed.). Beirut, Dar al-Ketab al-Arabi.

Amoli, Shams al-Din Mohammad bin Mahmoud. (2000). Nafaes Alfonun Fi Araes Al-Ayun, the publication of Dar Al-Kotob Islamiyah, Tehran.

Ansari, M. Ibn Mohammed Amin. (1993). the book of Almakaseb, J1, World Congress in honor of Sheikh Ansari, Qom.

Barraj Ibn, A. (1984). Almahzab. Islamic Publications affiliated with the Society of Teachers of Qom.

Bojnoordi, S. H. (1997). jurisprudential-rule (Vol. 4, 1st ed.). Al-Hadi publishing, Qom.

Buty, R. (1984). Zavabet Al-Maslaha. Institute of Al-Resale, Beirut.

Enayat, H. (1991). Tracing Arab political thought. Amir Kabir, Tehran.

Ghazali, A. H. (1997). Al-Mostafy Men Elm Al-Osul (Vol. 1, 1st ed.). Al-Resale Institute.

Ghazali, A. H. (2000). Rehabilitation of Sciences of religion (Vol. 1). Dar Ibn Hazm, Beirut.

Ghazali, M. M. (1991). Al-Mostafa, research of Mohammed Abdul Salam Abd Al-Shafei, Dar Al-Kotob Al-Elmiye, Beirut.

Hassani, I. (1995). theory of Al-Maghased End Al-Emam Mohammad Al-Taher Ibn Ashur, Al-Mahad al-Alami Lelfekr Al-Eslami.

Hosseini Rouhani, S. M. (1998). Al-Martaqy Ela Al-Feghh Al-Arqy-Al-khyarat book (Vol. 2). Institute of Al-Jalil Leltahghighat Al-Saghafi (Dar Al-Jali), Tehran.

Ibn Abedin, M. A. 'U. (1973). set of Epistles of Ibn Abedin (Vol. 2). Dar Ahya al-Taras Al-Arabi.

Ibn Albaraj, A. A. (1973). describe sentences of science and action. Mashhad, Hamu, Mahzab.

Ibn Ghayem, A. (1973). Elam Al-Mogheien (Vol. 3). Dar Al-jil, Beirut.

${ }^{31}$ Famous narrative of fertilization of palm trees, See: (Moslem Ibn Al-hajaj, 1985)

${ }^{32}$ The problem of development is not denied, for example, by emphasizing of some of the scholars with the school of thought mention here: Helli says:" provisions in Islamic law are subject to interests and interests by changing different time and by the difference of obliged people will be different. With this account it is possible that a certain sentence for people at a particular time is interesting and it is ordered, but for people in other time is evil and should be prohibited." (Allameh Helli , 1985)

Shahid Aval, says: "provisions is permissible to change habits to change as conventional weights and cost of women and relatives because they follow time habit that were in it, as well as appreciation and income." (Shahid Aval, 1974)

Mohaghegh Ardabil has remarkable thing when he says: "it is not possible a general theory expressed in the law, because provisions for credit of characteristics, the position of people, time, place and persons will be different, and it is a clear thing and special privileges is for the scholars and jurists who can understand these differences and changes and adapt the provisions on issues and topics that is the purpose of law." (Mohaghegh Ardabili, 1989) 
Ibn Ghayem, A. (1987). Aghaseh Al-lahfan (Vol. 1, 4th ed.). Maktabeh Wahbe, Cairo.

Ibn Manzur, Abu al-Fazl Jamal al-Din Mohammad ibn Mokarram. (1983). Lesan Al-Arab (Vol. 6). Publishing of Adab Al-Hoze.

Jarjani, Sayed Sharif Ali bin Mohammad. (1884). Al-Taryfat (Vol. 1). Al-Matba Al-Kheyrie Al-Mansha.

Kashef Al-ghata, Ja'far ibn al-Khezer. (2000). describing rules. Saeed bin Jubair.

Kelini, Mohammad ibn Ya'qub. (1985). al-Kafi (Vol. 3, 4th ed.). Dar Al-Kotob Islamiyah, Tehran.

Khoi, Abu al-Ghasem. (1990). Mu'jam Rejal Al-Hadith (Vol. 4). Medina Al-Elm, Qom.

Khomeini, S. M. M. (1996). Al-Sum book. Institute for Compilation and publication of Imam Khomeini, Tehran.

Khomeini, S. R. (1999). the book of Altahare, J4, Institute for Compilation and Publication of Imam Khomeini's Works, Tehran,.

Langroodi, P. (2001). general introduction of law. library of Ganj Danesh, Tehran.

Makarem Shirazi, N. (1989). jurisprudential-rule (Vol. 2). School of Imam (pbuh), Qom.

Makarem Shirazi, N. (1995). the role of time and place in Ijtihad, Collection of Works, Congress of review the fundamentals of jurisprudence, Imam Khomeini (Vol. 14). Institute for Compilation and Publication of the Works, Tehran.

Meshkini, A. (1969). terms of principle. Yasser, Qom.

Moghniye, M. J. (1989). al-Islam Benzare Asriye. Dar al-Niyar al-Jadid (Dar al-Javad), Beirut, IV.

Mohaghegh Ardabili, A. M. (1989). Assembly of Al-Faydeh and al-Borhan (Vol. 3). Islamic Publications Office, Qom.

Mohaghegh Damad Yazdi, S. M. (1984). the rules of jurisprudence (Vol. 1, 12th ed.). Press Center of Islamic Sciences, Tehran.

Mohaghegh Heli, J. B. H. (1985). Almotabar Fi Sharh Al-Mokhtasar, J1, Sayed Alshohada Institute, Qom.

Mohaghegh Qomi, Abu al-Qasim bin Mohammed Hassan. (1991). Jame Al-shatat Fi Ajuba Al-soalat, J2, Kayhan Institute, Tehran.

Mohammadi, Abu al-Hassan. (2004). the principles of understanding of Islamic Law. Tehran University Press.

Mojtahed shabestari, M. (1996). Three types of knowledge in the Three Realms, review, No. 5, p 298.

Montazeri, H. A. (1987). principles of jurisprudence of Islamic state, translator: Salavati, Mahmoud etc. (Vol. 8). Keyhan Institute, Qom.

Montazeri, H. A. (1992). Derasat Fi Al-Makaseb Al-Mahrame (Vol. 2). publishing of Tafakor, Qom.

Motahari, M. (1955). Islam and requirements of the time (Vol. 8). Sadra.

Motahhari, M. (1975). the finality of prophethood. Sadra, Qom.

Naeini, M. H. (1989). the book of Al-Sala (Vol. 1). Islamic Publications office affiliated to the society of seminary teachers of Qom.

Naeini, M. H. (1991). Al-makaseb and Al-Bei (Vol. 2). Islamic Publications Office affiliated with the society of seminary teachers of Qom.

Saberi, H. (2006). from the occasion to appeal jurisprudence, ways to religious purposes. Journal of Islamic studies, (71), 120.

Sadr, M. B. (1987). courses in science of principle (Vol. 4). Beirut, Dar Al-Ketab Al-Lobnani.

Shahid Aval, M. I. M. (1974a). rules and benefits. Maktabeh Mofid, Qom.

Shahid Aval, M. I. M. (1974b). The benefits of rules (Vol. 1). Maktabeh Mofid, Qom.

Shahid Aval, M. I.M. (1997). mention Shi'a in the provisions of Sharia. Al Bayt Institute, Qom.

Shahid Sani, Zin Al-Din Ibn Ali. (1991). Masalek Alafham Ela Tanghih Sharia Islam (Vol. 7). Institute on Islamic Encyclopedia, Qom.

Shateby, A. E. (1997). agreement in Sharia principles (Vol. 2, 1st ed.). Dar Al-Kotob Al-Elmiye, Beirut.

Shaykh Tusi, M. I. H. (1996). Al-Eghtesad al-Hadi Ela Tarigh al-Reshad, published by comprehensive library of forty columns, Tehran. 
Sobhi, S. (1982). Maalem al-Sharia Al-Eslamiye. Dar Al-Elm Lelmalaiyn, Beirut.

Tabatabaei Yazdi, M. K. (1999). margins of Almakaseb (Vol. 2). Ismailis Institute, Qom.

Tabatabaei, M. H. (1984). al-Mizan (Vol. 6). Ismaeiliyan, Qom.

Tabatabai, A. Z. (1952). Tanghih Al-Osul. press of Heydarieh, Najaf.

Valaiy, I. (2011). legal rules. published by Dar Al-fekr, Qom.

Zarqa, A. M. (1952), Al-Madkhal al-feqhi Al-Am Ela Al-Hoghogh Al-Madaniya Fi Balad Al-Suriya, vol. 2, p. 924, Second Edition.

Ziaee Bigdeli, M. R. (1987). Islamic and international law. the corporation of Enteshar, Tehran.

\section{Copyrights}

Copyright for this article is retained by the author(s), with first publication rights granted to the journal.

This is an open-access article distributed under the terms and conditions of the Creative Commons Attribution license (http://creativecommons.org/licenses/by/4.0/). 